\section{Economic Contributions of the Green Industry in the United States in 2013}

\author{
Alan W. Hodges ${ }^{1,5}$, Charles R. Hall ${ }^{2}$, Marco A. Palma ${ }^{3}$, and \\ Hayk Khachatryan ${ }^{4}$
}

ADDiTIONAL INDEX WORDS. sales, industry output, employment, value added, gross domestic product, production, manufacturing, landscaping services, wholesale, retail, lawn and garden product line

SUMMARY. Economic contributions of the green industry in the United States were estimated for 2013 using information on industry output, value added, employment and domestic/international exports, retail sector lawn and garden product sales, and economic multipliers from Impact Analysis for Planning (IMPLAN) regional economic models for each state. Direct industry output for all sectors was estimated at $\$ 136.44$ billion (B), and total output contributions, including indirect and induced regional economic multiplier effects of export sales, were \$196.07 B. The total value-added contribution to gross domestic product (GDP) was \$120.71 $\mathrm{B}$, including labor income contributions of $\$ 82.47 \mathrm{~B}$, other property income contributions of $\$ 28.91 \mathrm{~B}$ and business taxes paid to local, state, and federal governments of $\$ 9.30 \mathrm{~B}$. The industry had direct employment of $1,599,662$ fulltime and part-time jobs, and total employment contributions of $2,035,636$ jobs in the broader economy. The largest individual industry sectors in terms of employment and GDP contributions were landscaping and horticultural services $(1,105,526$ jobs, $\$ 54.70 \mathrm{~B})$; greenhouse, nursery, and floriculture production $(240,809$ jobs, $\$ 20.36 \mathrm{~B})$; and lawn and garden equipment and supplies stores $(217,798$ jobs, $\$ 12.87 \mathrm{~B})$. The top 10 states in terms of employment contributions were California $(245,267$ jobs), Florida $(197,073)$, Texas $(149,364)$, Ohio $(77,664)$, Pennsylvania $(77,569)$, Illinois $(76,254)$, New York $(73,676)$, North Carolina (72,014), Georgia $(64,066)$, and Michigan $(63,189)$. Green industry contributions represented $0.72 \%$ of U.S. GDP and $1.11 \%$ of total workforce employment, and it contributed over $1.0 \%$ of GDP in five states, and over $1.25 \%$ of employment in 10 states. Employment contributions averaged 0.6 jobs $/ \mathrm{mile}^{2}$ of land area and 6.4 jobs per 1000 persons in the U.S. population, while GDP contributions averaged $\$ 34,176 / \mathrm{mile}^{2}$ and $\$ 382$ per capita. Since $2007-08$, green industry contributions in 2013 increased by $4.4 \%$ for employment and $2.7 \%$ for GDP in inflation-adjusted terms. Growth in the industry was highest for wholesale and retail trade, whereas production and manufacturing declined. Although the green industry has grown slowly in recent years, it remains an important contributor to national, state, and local economies.

$\mathrm{T}$ The U.S. environmental horticulture industry, or green industry, is comprised of wholesale nursery, greenhouse, turfgrass sod producers, landscape design, construction and maintenance firms, and wholesale and retail distribution firms such as garden centers, home stores, mass merchandisers with lawn/garden departments, brokers and rewholesale

${ }^{1}$ Food and Resource Economics Department, University of Florida, P.O. Box 110240, Gainesville, FI 32611

${ }^{2}$ Department of Horticultural Sciences, Texas A\&M University, 202 Horticulture/Forest Science Building, 2133 TAMU, College Station, TX 77843

${ }^{3}$ Department of Agricultural Economics, Texas A\&M University, 2124 TAMU, College Station, TX

${ }^{4}$ Mid-Florida Research and Education Center, University of Florida, 2725 South Binion Road, Apopka, FL 32703

${ }^{5}$ Corresponding author. E-mail: awhodges@ufl.edu. distribution centers, and allied trade suppliers of inputs to the industry.

The green industry has historically been a fast-growing segment of the U.S. economy. However, the industry has reached the mature stage of its life cycle and is now growing slowly or even declining in some segments (Hall, 2010). According to the data from the Quarterly Census of Employment and Wages (U.S. Department of Labor, 2015), employment in the principal sectors of the U.S. green industry reached a peak of 1.285 million jobs in 2007, then dropped sharply during the global recession of 2008-10. As of 2013, industry employment had recovered somewhat but had not yet returned to prerecession levels. Over the 200113 period, total employment in the industry declined by $-0.4 \%$, although this varied widely among specific industry sectors, with strong positive growth for landscaping services $(+24.6 \%)$, but decreased for florists $(-49.3 \%)$, landscape architectural services $(-28.2 \%)$, lawn and garden equipment manufacturing $(-20.8 \%)$, and nursery and floriculture production (-9.0\%) (Fig. 1). Employment for most sectors increased during 2001-07, then declined during the recession of 2007-09, and recovered during 2011-13, but remained below the peak level in 2007. The only industry sector showing steadily downward trending employment was florists, consistent with the decreasing number of brick-and-mortar establishments. The number of business establishments in the green industry also declined during the recession, and has not recovered, in part due to consolidation and increasing concentration in the industry (Hall, 2010). The housing sector collapse during the recession revealed that the rate of industry growth was unsustainable.

Recognizing the limitations of existing data sources and the critical need for economic impact information, numerous state nursery and landscape industry organizations have sponsored economic impact studies for their respective states. For example, studies were conducted in Florida (Hodges et al., 201la), Louisiana (Hinson et al., 2003), and Colorado (Thilmany et al., 2003). Stakeholders have found these studies to be useful in communicating the importance of the green industry to policymakers to gain assistance and resources, and in combating proposed legislation that would negatively impact the industry. However, direct comparison of these results across states is complicated because of differences in research methods used in these studies. For example, some states used mail, telephone, or personal interview surveys to collect primary data, whereas

\begin{tabular}{llll}
\hline $\begin{array}{l}\text { Units } \\
\text { To convert U.S. to SI, } \\
\text { multiply by }\end{array}$ & U.S. unit & SI unit & $\begin{array}{l}\text { To convert SI to U.S., } \\
\text { multiply by }\end{array}$ \\
\hline 2.5900 & mile $^{2}$ & $\mathrm{~km}^{2}$ & 0.3861
\end{tabular}




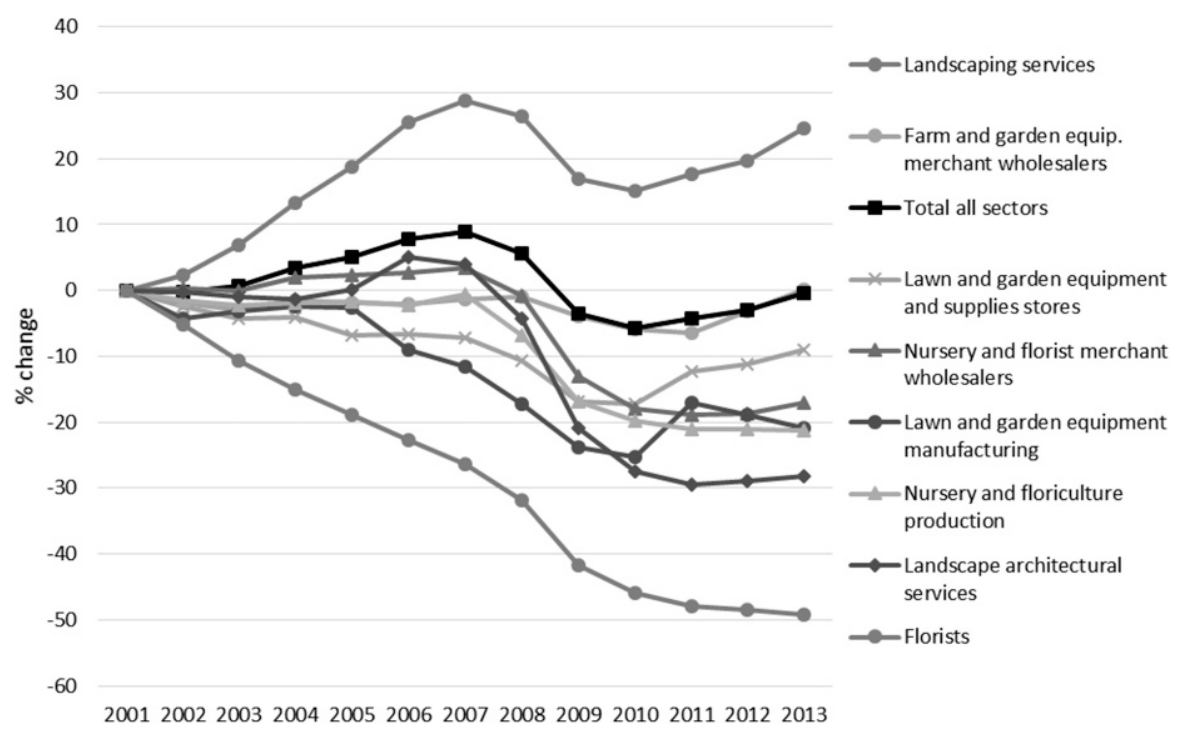

Fig. 1. Change in direct employment in primary sectors of the U.S. green industry from 2001 through 2013 (U.S. Department of Labor, 2015).

others relied on secondary data sources. Another important difference is the number and type of sectors that were included in each respective study, with some states including end users such as households, golf courses, and sports complexes, whereas others did not. Also, the regional economic models used to determine economic multipliers differed between studies. These factors point to the need to conduct a comprehensive national study that uses a common methodology to collect industry data and calculate associated economic contributions.

The first attempt to develop an internally consistent estimate of state and national economic contributions of the green industry was reported by Hall et al. (2006), with total national economic contributions of the industry in 2002 given as 1.96 million fulltime and part-time jobs, $\$ 147.8 \mathrm{~B}$ in industry output, and $\$ 95.1 \mathrm{~B}$ in value added or GDP, expressed in 2004 dollars. In a follow-up study for 2007-08, the total national contributions of the industry were estimated at 1.95 million jobs, $\$ 175.26 \mathrm{~B}$ in industry output, and $\$ 107.16 \mathrm{~B}$ in GDP (Hodges et al., 2011b). The largest individual industry sectors in 2007-08 in terms of employment and GDP contributions were landscaping services $(1,075,343$ jobs, $\$ 50.3 \mathrm{~B})$, nursery, and greenhouse production (436,462 jobs, \$27.1 B), and building materials and garden equipment and supplies stores (190,839 jobs, $\$ 9.7 \mathrm{~B})$. The top 10 individual states in terms of employment contributions were California (257,885 jobs), Florida $(188,437)$, Texas $(82,113)$, North Carolina $(81,113)$, Ohio $(79,707)$, Pennsylvania $(75,604)$, New Jersey $(67,993)$, Illinois $(67,382)$, Georgia $(66,042)$, and Virginia $(58,677)$. The green industry represented $0.76 \%$ of U.S. GDP in 2008 .

The objective of this paper is to update the previous estimates of the economic contributions of the green industry in 2013 at the national and state levels, by using a consistent set of nationwide data to enable reliable comparisons among U.S. states and regions. This information can be used to inform public policy and support efforts by industry stakeholders to communicate the importance of the industry.

\section{Materials and methods}

Economic sectors associated with the green industry were identified based on definitions in the North American Industry Classification System [NAICS (U.S. Department of Commerce, 2015c)]. The production and manufacturing industry group includes the sectors for nursery, greenhouse, and floriculture production (NAICS 11142) and lawn and garden equipment manufacturing (333112). The landscape design, construction, and maintenance services industry group includes the sectors landscaping services (56173) and landscape architectural services (54132).
The wholesale and retail distribution industry group includes farm and garden equipment merchant wholesalers (423820), nursery and florist merchant wholesalers (42493), lawn and garden equipment and supplies stores (4442), and florists (4531). These green industry sectors collectively had a total of 155,900 business establishments, with $1,173,894$ direct employees, and $\$ 37.55$ $B$ in wages paid in 2013 (Table 1 ). In addition, retail sectors that have significant sales of horticultural merchandise were included in the study.

State level economic data on industry output, value added, employment, labor income, other property income, business taxes, and domestic and international exports for green industry sectors were compiled from the IMPLAN database for 2013 (IMPLAN Group, LLC, 2015). These data were derived from a variety of sources, including the Quarterly Census of Employment and Wages, state and national GDP and personal income statistics, the Economic Census and Census of Agriculture, which are considered very reliable sources, with a well-established methodology, adjustment for nonresponding firms, and published statistical confidence parameters. Note that information on employment in the IMPLAN database may differ from that given by the Quarterly Census of Employment and Wages due to adjustments for nonemployer sole proprietor firms.

For some industry sectors in the IMPLAN data, the proportion of activity attributable to horticulturerelated activity was determined based on the share of employment in the parent NAICS sector: landscape architectural services within architectural and engineering services, florists within miscellaneous store retailers, and nursery and florist merchant wholesalers and farm and garden equipment merchant wholesalers within wholesale trade. The farm and garden equipment wholesaler sector was further subdivided to estimate for garden equipment only (excluding farm equipment).

For all of the retail sectors, except florists, green industry economic contributions were estimated using data on lawn, garden, and farm equipment and supplies sales as a share of total U.S. retail sales reported in the 2012 economic census (U.S. Department of Commerce, 2015b), as shown in Table 2 . The largest retail 
Table 1. Number of business establishments, number of employees, and wages paid in principal sectors of the U.S. green industry in 2013 (U.S. Department of Labor, 2015).

\begin{tabular}{|c|c|c|c|}
\hline Industry sector (NAICS code $)^{\mathrm{z}}$ & $\begin{array}{c}\text { Business } \\
\text { establishments (no.) }\end{array}$ & Employees (no.) & $\begin{array}{c}\text { Wages } \\
\text { paid ( } \$ \text { million })\end{array}$ \\
\hline Landscaping services $(56173)$ & 98,857 & 653,995 & 19,787 \\
\hline Lawn and garden equipment and supplies stores (4442) & 16,836 & 141,697 & 5,468 \\
\hline Nursery and floriculture production (11142) & 14,334 & 122,399 & 4,093 \\
\hline Farm and garden equipment merchant wholesalers (423820) & 8,117 & 102,423 & 3,394 \\
\hline Florists $(4531)$ & 7,616 & 63,248 & 1,588 \\
\hline Lawn and garden equipment manufacturing (333112) & 238 & 17,295 & 664 \\
\hline Total & 155,900 & $\underline{1,173,894}$ & $\underline{37,551}$ \\
\hline
\end{tabular}

${ }^{2}$ North American Industry Classification System (U.S. Department of Commerce, 2015c).

Table 2. Retail sector product line sales of lawn, garden, farm equipment and supplies, and share of total sales in the U.S. in 2012 (U.S. Department of Commerce, 2015b).

\begin{tabular}{lccc}
\hline & $\begin{array}{c}\text { Business } \\
\text { establishments } \\
\text { selling product } \\
\text { line (no.) }\end{array}$ & $\begin{array}{c}\text { Product line } \\
\text { sales (\$ million) }\end{array}$ & $\begin{array}{c}\text { Total sales of } \\
\text { all establishments } \\
\text { (\$ million) }\end{array}$ \\
\hline Building material and garden equipment & 34,770 & 50,078 & $\begin{array}{c}\text { Product line } \\
\text { sales as share } \\
\text { of total sales (\%) }\end{array}$ \\
$\quad$ and supplies dealers (444) & 31,113 & 10,817 & 17.92 \\
Food and beverage stores (445) & 15,842 & 8,438 & 621,698 \\
General merchandise stores (452) & 2,465 & 5,995 & 641,353 \\
Nonstore retailers (454) & 16,614 & 4,056 & 384,054 \\
Miscellaneous store retailers (453) & 1,406 & 361 & 97,647 \\
Gasoline stations (447) & $\underline{102,210}$ & $\underline{79,745}$ & 1.74 \\
Total for sectors used in analysis & $\underline{554,241}$ & $\underline{2,578,468}$ \\
\hline
\end{tabular}

${ }^{2}$ North American Industry Classification System (U.S. Department of Commerce, 2015c).

'Excludes retail sectors with relatively small values: health and personal care stores (446), motor vehicle and parts dealers (441), sporting goods stores (451), furniture stores (442), electronics and appliance stores (443), and clothing stores (448).

sectors for product line sales were building material and garden equipment and supplies dealers (\$50.08 B), food and beverage stores $(\$ 10.82 \mathrm{~B})$, general merchandise stores $(\$ 8.44$ $\mathrm{B})$, nonstore retailers $(\$ 6.00 \mathrm{~B})$, miscellaneous store retailers $(\$ 4.06 \mathrm{~B})$, and gasoline stations (\$361 million). The product line sales represented $17.9 \%$ of total sector sales for building material and garden equipment and supplies dealers, $4.2 \%$ for miscellaneous store retailers, and less than $2 \%$ for the other sectors. Some retail sectors were not included in the analysis because the lawn and garden product sales were relatively minor and represented less than $1 \%$ of total sales: health and personal care stores, motor vehicle and parts dealers, sporting goods stores, furniture stores, electronics and appliance stores, and clothing stores. Specific lawn and garden product lines reported included outdoor nursery stock; indoor potted plants and floral items; cut flowers; fertilizer, lime, chemicals, and other soil treatments; lawn and garden

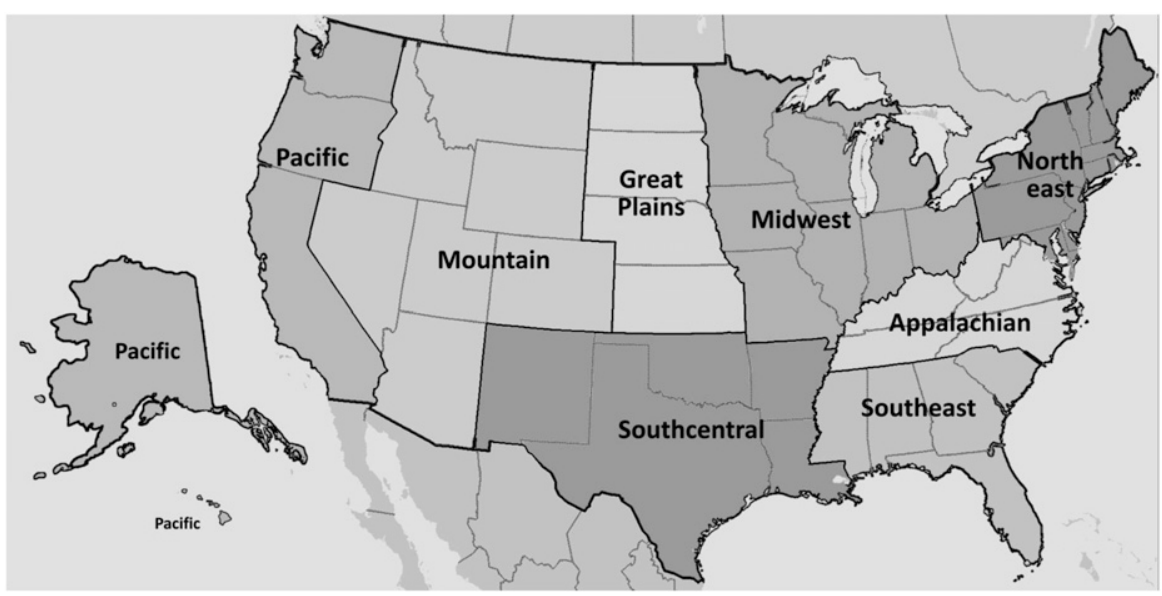

Fig. 2. Map of U.S. agroclimatic regions for economic contribution analysis of the green industry.

equipment and tools; materials used in landscaping or lawn service; and artificial/silk flowers plants trees. These specific items totaled $\$ 50.55 \mathrm{~B}$, or $81.8 \%$ of total itemized sales within the broad product line of lawn, garden, and farm equipment and supplies. The share of total sales in each retail sector and state were estimated using the percentage of total national sales of the broad product line in 2012, adjusted for the share of sales of specific horticultural products net of farm-related equipment and supplies (81.8\%), and further adjusted for the state-level share of product line sales from the 2007 economic census (U.S. Department of Commerce, 2009). 
The regional economic contributions of green industry sectors in each state were evaluated using economic multipliers from the IMPLAN Input-Output/Social Accounting Matrix software, with models created for each state (IMPLAN Group, LLC, 2015). These models represent the structure of a regional economy in terms of transactions between industries, employees, households, and government institutions (Miller and Blair, 2009). The IMPLAN modeling system contains regional economic data for 536 industry sectors, including commodity production, employment, household income, commodity trade, capital investment, taxes, transfer payments (e.g., welfare, retirement pensions), and gross margins for wholesale and retail trade sectors, which represent the share of sales that constitute final demand after subtracting the cost of goods sold. Final demand economic multipliers from IMPLAN were used to estimate the total economic activity generated from in-state sales and export sales. The multipliers captured the effects of product or service sales (direct effects), supply chain purchases by industry firms from other economic sectors (indirect effects) and employee household consumer spending, and local, state, and federal government spending (induced effects). Separate multipliers were used for industry output (sales revenues or receipts), employment, value added, and labor income (earnings). The multipliers for output, value added, labor income, other property income and business taxes are expressed in units of dollars per dollar output, whereas the multipliers for employment are expressed in jobs per million dollars final demand. Differences in multiplier values reflect the structure of industry sectors, the degree of economic integration, and the mix of supplier industries available to meet local demands in each state. The economic multipliers were applied to industry sales to estimate total economic contributions using the formula: $\mathrm{I}_{\mathrm{hij}}=\mathrm{S}_{\mathrm{hi}} \times\left[\mathrm{A}_{\mathrm{hij}}+\mathrm{E}_{\mathrm{hi}} \times\right.$ $\left.\left(\mathrm{B}_{\text {hij }}+\mathrm{C}_{\text {hij }}\right)\right]$, where $\mathrm{I}_{\text {hij }}$ is total impact

Table 3. Economic contributions of U.S. green industry groups and sectors in 2013 (IMPLAN Group, LLC, 2015).

\begin{tabular}{|c|c|c|c|c|c|c|c|c|c|}
\hline \multirow[b]{3}{*}{ Industry group/sector } & \multirow[b]{2}{*}{$\begin{array}{c}\text { Direct } \\
\text { employment }\end{array}$} & \multirow[b]{2}{*}{$\begin{array}{l}\text { Employment } \\
\text { contribution }^{z}\end{array}$} & \multirow[b]{2}{*}{$\begin{array}{l}\text { Direct } \\
\text { industry } \\
\text { output }\end{array}$} & \multirow[b]{2}{*}{$\begin{array}{l}\text { Domestic and } \\
\text { international } \\
\text { exports }\end{array}$} & \multicolumn{5}{|c|}{ Economic contribution ${ }^{\mathrm{z}}$} \\
\hline & & & & & Industry & $\begin{array}{c}\text { Gross } \\
\text { Domestic } \\
\text { Product }\end{array}$ & $\begin{array}{l}\text { Labor } \\
\text { income }\end{array}$ & $\begin{array}{l}\text { Other } \\
\text { property } \\
\text { income }\end{array}$ & Business \\
\hline & $\begin{array}{r}\text { Full-ti } \\
\text { part-time }\end{array}$ & $\begin{array}{l}\text { ime and } \\
\text { jobs (no.) }\end{array}$ & & & & $\frac{\text { Product }}{\text { million }}$ & & & \\
\hline $\begin{array}{l}\text { Production and } \\
\text { manufacturing }\end{array}$ & 152,614 & 291,853 & 25,900 & 14,624 & 45,615 & 24,834 & 16,203 & 7,694 & 939 \\
\hline $\begin{array}{l}\text { Greenhouse, nursery, and } \\
\text { floriculture production }\end{array}$ & 134,471 & 240,809 & 16,766 & 9,104 & 31,252 & 20,358 & 13,709 & 5,938 & 713 \\
\hline $\begin{array}{l}\text { Lawn and garden } \\
\text { equipment } \\
\text { manufacturing }\end{array}$ & 18,143 & 51,043 & 9,135 & 5,520 & 14,363 & 4,476 & 2,494 & 1,756 & 225 \\
\hline $\begin{array}{l}\text { Landscape design, } \\
\text { construction, and } \\
\text { maintenance services }\end{array}$ & 959,208 & $1,164,237$ & 63,903 & 18,413 & 91,691 & 58,963 & 43,192 & 13,487 & 2,266 \\
\hline $\begin{array}{l}\text { Landscape and } \\
\text { horticultural services }\end{array}$ & 914,847 & $1,105,526$ & 58,284 & 17,356 & 84,169 & 54,697 & 38,903 & 13,637 & 2,141 \\
\hline $\begin{array}{l}\text { Landscape architectural } \\
\text { services }\end{array}$ & 44,361 & 58,710 & 5,619 & 1,057 & 7,522 & 4,266 & 4,290 & -150 & 125 \\
\hline $\begin{array}{l}\text { Wholesale and retail } \\
\text { distribution }\end{array}$ & 487,840 & 579,546 & 46,634 & 7,226 & 58,760 & 36,910 & 23,079 & 7,726 & 6,090 \\
\hline $\begin{array}{l}\text { Lawn and garden } \\
\text { equipment and supplies } \\
\text { stores }\end{array}$ & 194,987 & 217,798 & 18,127 & 1,801 & 21,009 & 12,869 & 8,478 & 2,238 & 2,141 \\
\hline Florists & 127,336 & 132,163 & 4,916 & 392 & 5,564 & 3,535 & 3,055 & -91 & 570 \\
\hline $\begin{array}{l}\text { Nursery and florist } \\
\text { merchant wholesalers }\end{array}$ & 46,693 & 84,242 & 10,872 & 2,908 & 15,951 & 10,328 & 5,767 & 2,908 & 1,653 \\
\hline $\begin{array}{l}\text { Food and beverage stores, } \\
\text { lawn and garden sales }\end{array}$ & 39,859 & 42,938 & 2,674 & 252 & 3,114 & 2,022 & 1,381 & 348 & 292 \\
\hline $\begin{array}{l}\text { Farm and garden } \\
\text { equipment merchant } \\
\text { wholesalers }\end{array}$ & 23,344 & 39,396 & 5,244 & 1,272 & 7,336 & 4,669 & 2,602 & 1,339 & 726 \\
\hline $\begin{array}{l}\text { General merchandise } \\
\text { stores, lawn, and } \\
\text { garden sales }\end{array}$ & 32,287 & 35,436 & 2,265 & 232 & 2,668 & 1,647 & 1,033 & 206 & 407 \\
\hline $\begin{array}{l}\text { Nonstore retailers, lawn, } \\
\text { and garden sales }\end{array}$ & 22,749 & 26,860 & 2,495 & 358 & 3,062 & 1,807 & 738 & 773 & 297 \\
\hline $\begin{array}{l}\text { Gasoline stores, lawn, and } \\
\text { garden sales }\end{array}$ & 585 & 713 & 41 & 11 & 57 & 35 & 25 & 5 & 5 \\
\hline Total all sectors & $1,599,662$ & $2,035,636$ & 136,438 & $\underline{40,263}$ & 196,066 & $\underline{120,707}$ & 82,474 & 28,906 & 9,295 \\
\hline
\end{tabular}

${ }^{2}$ Economic contribution estimates include indirect and induced regional multiplier effects. 
for measures ( $j$ ) of output, employment, value added, labor income, other property income or business taxes, in sector (i), and state (h), $S_{h i}$ is industry sales or output, $A_{\text {hij }}$ is the direct effects multiplier, $\mathrm{E}_{\mathrm{hi}}$ is the proportion of industry sales exported to domestic or international markets, $\mathrm{B}_{\mathrm{hij}}$ is the indirect effects multiplier, and $\mathrm{C}_{\mathrm{hij}}$ is the induced effects multiplier. The calculation treats only the export portion of output as new final demand, which is subject to the full multipliers effects (direct, indirect, and induced), while in-state sales reflect intermediate demand from other business sectors and are subject only to the direct effects multipliers. The economic analysis results were compiled and reported for each industry sector and individual states within eight agroclimatic regions of the United States, as shown in Fig. 2, that are similar to farm production regions defined by the U.S. Department of Agriculture (2000). The results are described interchangeably as economic contributions or impacts, although it is understood that these values represent the ongoing activity in the industry rather than a net change in economic activity (Watson et al., 2007).

\section{Results and discussion}

The estimated total economic contributions of the U.S. green industry in 2013 were summarized by industry groups and sectors (Table 3 ; Figs. 3 and 4). Direct industry output or sales revenues for all sectors was \$136.44 B. Domestic and international exports (out-of-state sales) of goods and services were $\$ 40.26 \mathrm{~B}$. The total output contribution, including indirect and induced regional economic multiplier effects of exports, was \$196.07 B. Direct employment by green industry firms was $1,599,662$ full-time and part-time jobs, and the total employment contribution (including multiplier effects) in the broader economy was $2,035,636$ jobs. The total value-added or GDP contribution was $\$ 120.71 \mathrm{~B}$. The labor income contribution, representing employee compensation, benefits, and business owner income, was $\$ 82.47$ $\mathrm{B}$, the property income contribution, representing rents, royalties, corporate dividends, capital gains, and interest, was $\$ 28.91 \mathrm{~B}$, and the contribution of $\$ 9.30 \mathrm{~B}$ in business taxes on sales, property, payroll, excise, motor vehicle, fuels, etc. that were paid to local, state, and federal governments.

The production and manufacturing industry group, including the sectors nursery and greenhouse production and lawn and garden equipment manufacturing, had contributions of $\$ 45.62 \mathrm{~B}$ in output, $\$ 24.83 \mathrm{~B}$ to GDP, $\$ 16.20 \mathrm{~B}$ in labor income, $\$ 7.69$ $B$ in other property income, and 291,853 jobs (Table 3 ). This industry group represented $23.3 \%$ of total output contributions, $20.6 \%$ of GDP contributions, and $14.3 \%$ of employment contributions. The landscape design, construction, and maintenance services industry group, consisting of landscape and horticultural services and landscape architectural services firms, had contributions of $\$ 91.69 \mathrm{~B}$ in output, $\$ 58.96 \mathrm{~B}$ in GDP, $\$ 43.19 \mathrm{~B}$ in labor income, $\$ 13.49 \mathrm{~B}$ in other property income, and 1,164,237 jobs, which represented $46.8 \%, 48.8 \%$, and $57.2 \%$ of total green industry output, GDP, and employment contributions, respectively. The wholesale and retail distribution industry group had contributions of $\$ 58.76 \mathrm{~B}$ in output, $\$ 36.91$ $\mathrm{B}$ in GDP, \$23.08 B in labor income, $\$ 7.73 \mathrm{~B}$ in other property income, and

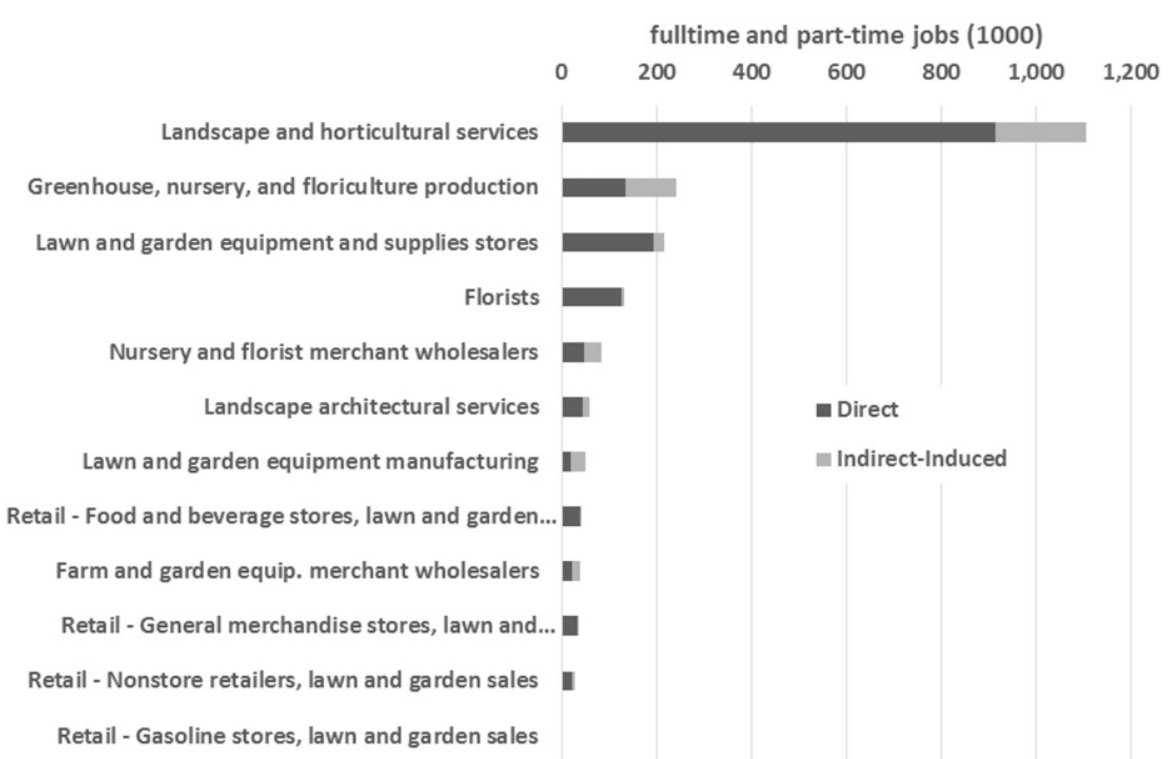

Fig. 3. Employment contributions of U.S. green industry sectors by direct- and indirect-induced multiplier effects in 2013 .

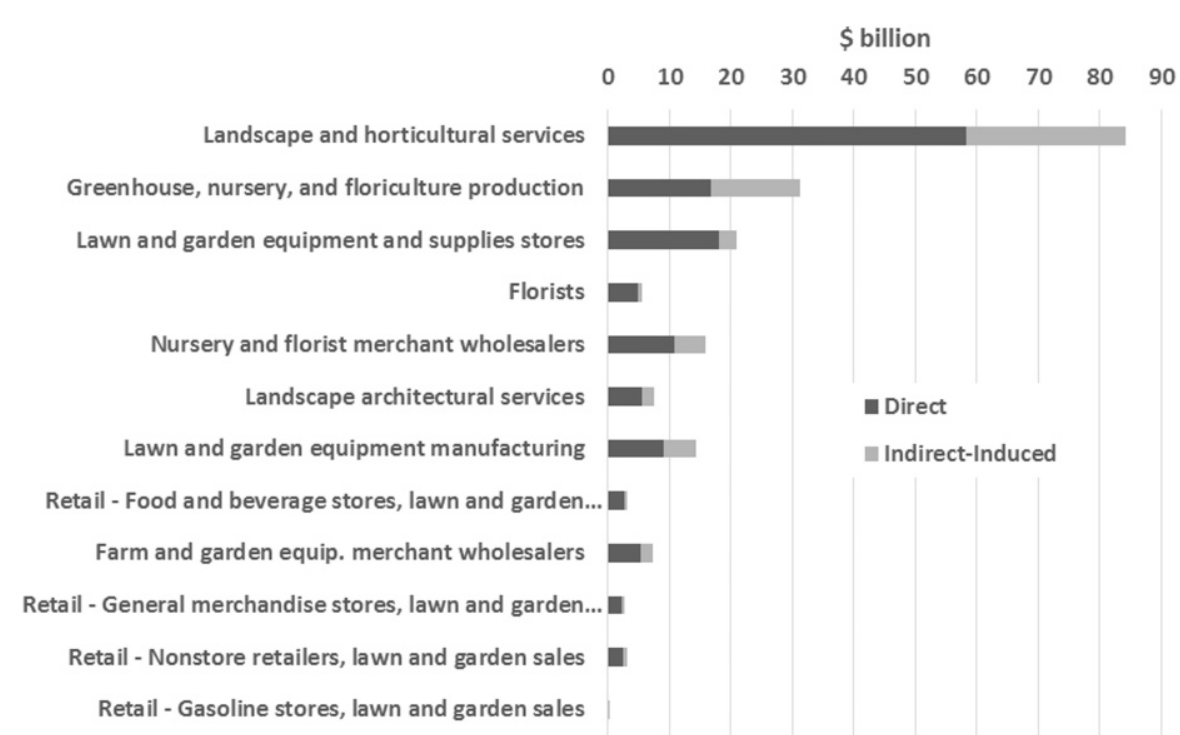

Fig. 4. Output contributions of U.S. green industry sectors by direct- and indirectinduced multiplier effects in 2013. 
579,546 jobs, representing $30.0 \%$, $30.6 \%$, and $28.5 \%$ of total green industry output, GDP, and employment contributions, respectively. This latter group also had the largest business tax contributions of $\$ 6.09 \mathrm{~B}$, mainly due to sales taxes on goods sold. Indirect and induced multiplier effects represented $30.4 \%$ of total output contributions for the overall green industry, while the share for production and manufacturing was higher $(43.2 \%)$ than for landscape services (30.3\%) and wholesale and retail distribution $(20.6 \%)$, because the producer sectors had a larger share of out-of-state sales, representing $56.5 \%$ of direct output.

By far the largest individual green industry sector was landscape and horticultural services, with contributions of $\$ 84.17 \mathrm{~B}$ in output, $\$ 54.70 \mathrm{~B}$ in GDP, and $1,105,526$ jobs (Figs. 3-5). The next largest industry sector was greenhouse, nursery, and floriculture production, with $\$ 31.25 \mathrm{~B}$ in output, $\$ 20.36 \mathrm{~B}$ in GDP, and 134,471 jobs. The largest retail sector was lawn and garden equipment and supplies stores, with contributions of $\$ 21.01 \mathrm{~B}$ in output, $\$ 12.87 \mathrm{~B}$ in GDP, and 217,798 jobs. Retail florists had contributions of $\$ 5.56 \mathrm{~B}$ in output, $\$ 3.54 \mathrm{~B}$ in GDP, and 132,163 jobs. Nursery and florist merchant wholesalers had contributions of $\$ 15.95 \mathrm{~B}$ in output, $\$ 10.33 \mathrm{~B}$ in GDP, and 84,242 jobs, while garden equipment merchant wholesalers had \$7.34 B, \$4.67 B, and 39,396 jobs, respectively. There were also

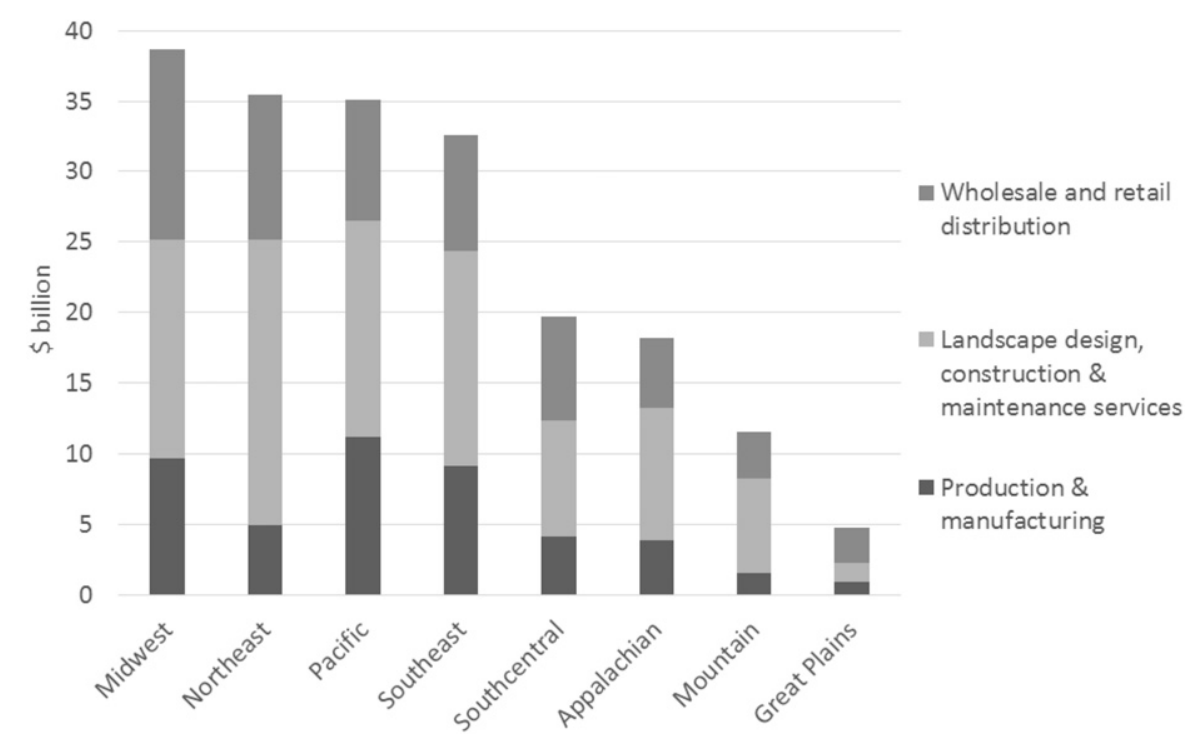

Fig. 5. Output contributions of green industry groups in U.S. agroclimatic regions in 2013.

significant contributions for lawn and garden product sales in the retail sectors by food and beverage stores (\$3.11 B output, \$2.02 B GDP, 42,938 jobs), nonstore retailers (\$3.06 B output, \$1.81 B GDP, 26,860 jobs), and general merchandise stores (\$2.69 B output, \$1.65 B GDP, 35,436 jobs). Lawn and garden equipment manufacturing contributed $\$ 14.36 \mathrm{~B}$ in output, $\$ 4.48 \mathrm{~B}$ in GDP, and 51,043 jobs. Landscape architectural services contributed $\$ 7.52 \mathrm{~B}$ in output, $\$ 4.27 \mathrm{~B}$ in GDP, and 58,710 jobs. Gasoline stores were the smallest sector evaluated, with contributions of $\$ 57$ million in output, $\$ 35$ million in GDP, and 713 jobs.

Economic contributions of the green industry in U.S. states and regions are summarized in Table 4 and Fig. 5. The largest regions in terms of employment contributions were the Midwest (387,748 jobs) and Northeast $(381,307)$, followed by the Southeast $(342,224)$, Pacific $(333,419)$, Southcentral (214,372), Appalachian $(199,553)$, Mountain $(130,579)$, and Great Plains $(46,435)$. Industry output contributions were over \$35 B and GDP contributions exceeded \$22 B in the Midwest, Northeast, and Pacific regions. The Southeast region had $\$ 32.62 \mathrm{~B}$ in output and $\$ 18.91 \mathrm{~B}$ in GDP. The Southcentral and Appalachian regions had over $\$ 18 \mathrm{~B}$ in output and \$10 B in GDP. The Mountain region had \$11.54 B in output and \$7.16 B in GDP. The
Great Plains regions had the lowest green industry contributions of $\$ 4.79 \mathrm{~B}$ in output and $\$ 2.79 \mathrm{~B}$ in GDP.

In terms of the relative importance of green industry sectors across regions, measured as the share of green industry employment, greenhouse, nursery, and floriculture production was most prominent in the Pacific (20.4\%), Southeast (12.8\%), Southcentral (11.7\%), and Northeast (11.1\%); landscape and horticultural services was highest in the Mountain (63.1\%), Northeast (58.4\%), Southeast (57.6\%), and Appalachian (56.7\%); lawn and garden equipment manufacturing was highest in the Midwest (5.5\%), Great Plains $(4.8 \%)$, and Southeast $(4.6 \%)$; retail lawn and garden stores were highest in the Great Plains $(23.8 \%)$, Midwest (14.2\%), Southcentral (13.7\%), and Appalachian (12.1\%); florists were highest in the Great Plains $(8.7 \%)$, Midwest (7.9\%), Northeast (7.8\%), and Southcentral $(7.5 \%)$; nonstore retailers were highest in the Midwest (2.3\%), Northeast (1.8\%), and Great Plains (1.6\%).

Among individual states, the top 10 states in terms of total employment and GDP contributions were California $(245,267$ jobs, \$17.27 B), Florida $(197,073$ jobs, \$10.82 B), Texas (149,364 jobs, $\$ 8.56$ B), Ohio (77,664 jobs, $\$ 4.43 \mathrm{~B})$, Pennsylvania $(77,569$ jobs, $\$ 4.46 \mathrm{~B})$, Illinois $(76,254$ jobs, $\$ 5.00$ B), New York $(73,676$ jobs, $\$ 4.60 \mathrm{~B})$, North Carolina $(72,014$ jobs, $\$ 4.14 \mathrm{~B})$, Georgia $(64,066$ jobs, $\$ 3.79 \mathrm{~B})$, and Michigan $(63,189$ jobs, $\$ 3.68 \mathrm{~B})$, as shown in Table 4. Other states with employment contributions exceeding 40,000 jobs and value-added contributions over \$2.6 B were New Jersey, Virginia, Maryland, Massachusetts, Tennessee, Wisconsin, and Washington. The top three states for total industry output contributions were California ( $\$ 26.60$ B), Florida (\$17.59 B), and Texas $\left(\begin{array}{ll}\$ 3.46 & B\end{array}\right)$, followed by Illinois (\$8.19 B), Ohio (\$7.66 B), Pennsylvania (\$6.99 B), New York (\$6.94 B), North Carolina (\$6.88 B), and Georgia $(\$ 6.72 \mathrm{~B})$. The largest employment contributions in the landscape services sector were in California (133,248 jobs), Florida (124,430 jobs), and Texas (79,018 jobs), which represented over half $(59.2 \%, 65.8 \%$, and $56.8 \%$, respectively) of total green 
Table 4. Economic contributions of the green industry in U.S. regions and states in 2013.

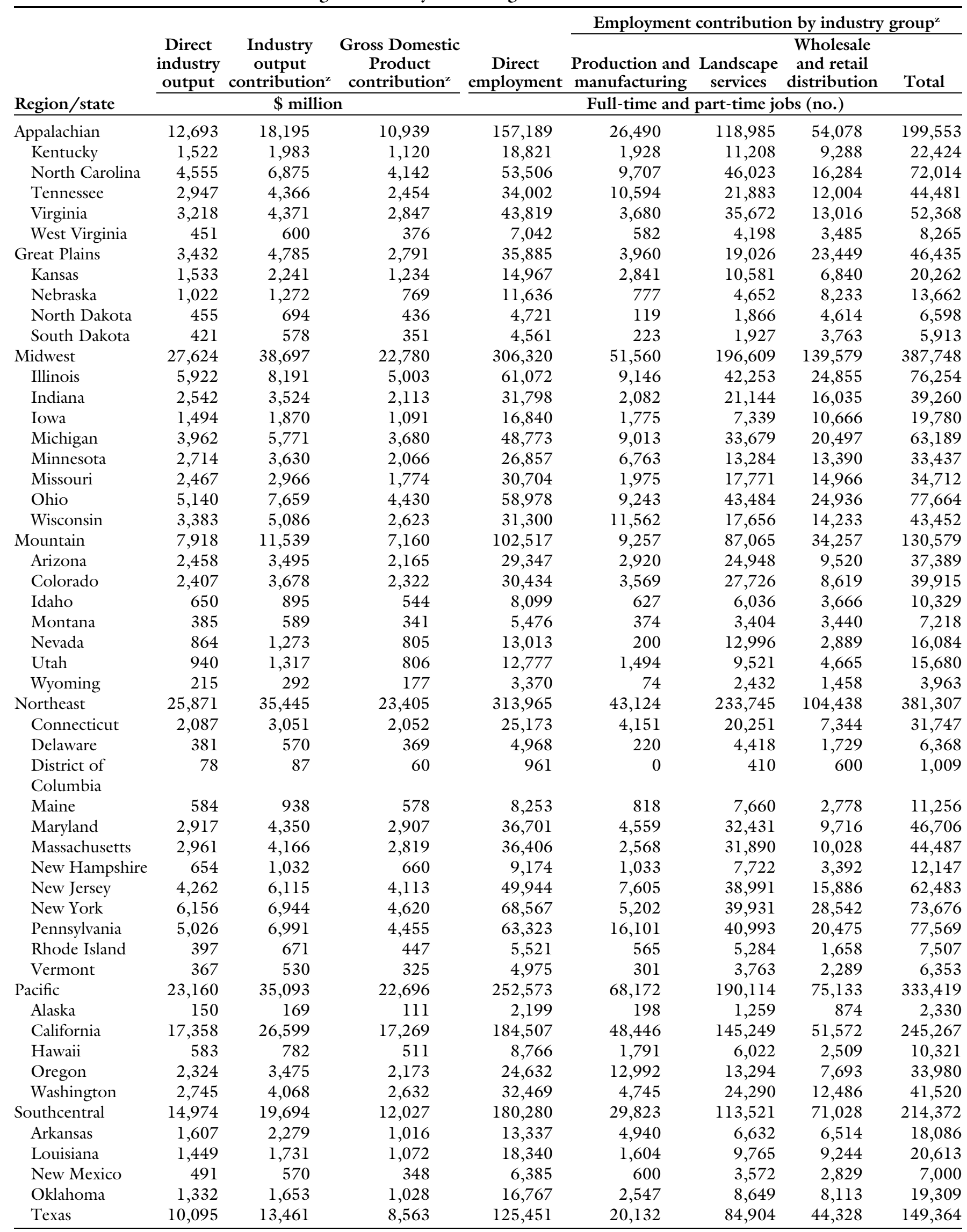

(Continued on next page) 
Table 4. (Continued) Economic contributions of the green industry in U.S. regions and states in 2013.

\begin{tabular}{|c|c|c|c|c|c|c|c|c|}
\hline \multirow{2}{*}{ Region/state } & \multirow[b]{2}{*}{$\begin{array}{c}\text { Direct } \\
\text { industry } \\
\text { output }\end{array}$} & \multirow[b]{2}{*}{$\begin{array}{c}\text { Industry } \\
\text { output } \\
\text { contribution }^{z}\end{array}$} & \multirow[b]{2}{*}{$\begin{array}{c}\text { Gross Domestic } \\
\text { Product } \\
\text { contribution }^{\mathrm{z}}\end{array}$} & \multirow[b]{2}{*}{$\begin{array}{c}\text { Direct } \\
\text { employment }\end{array}$} & \multicolumn{4}{|c|}{ Employment contribution by industry group ${ }^{z}$} \\
\hline & & & & & $\begin{array}{l}\text { Production and } \\
\text { manufacturing }\end{array}$ & $\begin{array}{c}\text { Landscape } \\
\text { services }\end{array}$ & $\begin{array}{l}\text { Wholesale } \\
\text { and retail } \\
\text { distribution }\end{array}$ & Total \\
\hline Southeast & 20,767 & 32,617 & 18,910 & 250,932 & 59,466 & 205,172 & 77,586 & 342,224 \\
\hline Alabama & 1,582 & 2,184 & 1,339 & 22,544 & 4,724 & 13,204 & 9,425 & 27,353 \\
\hline Mississippi & 1,168 & 1,625 & 835 & 12,390 & 2,329 & 7,009 & 6,483 & 15,821 \\
\hline South Carolina & 2,839 & 4,498 & 2,126 & 26,034 & 11,146 & 18,994 & 7,772 & 37,911 \\
\hline United States & $\underline{136,438}$ & $\underline{196,066}$ & 120,707 & $\underline{1,599,662}$ & 291,853 & $\underline{1,164,237}$ & $\underline{579,546}$ & $\underline{2,035,636}$ \\
\hline
\end{tabular}

${ }^{\mathrm{z} C o n t r i b u t i o n ~ e s t i m a t e s ~ i n c l u d e ~ i n d i r e c t ~ a n d ~ i n d u c e d ~ r e g i o n a l ~ m u l t i p l i e r ~ e f f e c t s . ~}$

industry contributions in those states. These same three states had the largest employment contributions for greenhouse, nursery, and floriculture production: 48,302 jobs in California, 29,090 jobs in Florida, 19,799 jobs in Texas. Employment contributions in the lawn and garden equipment manufacturing sector were highest in Wisconsin (8506 jobs), South Carolina (7112 jobs), and Georgia (6752 jobs).

As a measure of the relative economic importance of the green industry, the value-added or GDP contribution represented $0.72 \%$ of U.S. GDP, the labor income contribution was $0.81 \%$ of total wages, benefits, and proprietor income, and the employment contribution represented $1.11 \%$ of the U.S. workforce in 2013 (Table 5). The top five states with the highest percentage contribution to GDP by the green industry were Florida (1.36\%), South Carolina (1.13\%), Vermont (1.09\%), Oregon (1.05\%), and Maine (1.04\%). The top states in terms of percentage contribution to total employment were Florida (1.87\%), South Carolina (1.51\%), Vermont (1.49\%), Oregon (1.49\%), and New Hampshire (1.43\%), and an addition five states that were above $1.25 \%$, including Connecticut, Maine, Maryland, North Carolina, and Rhode Island.

The economic contributions of the green industry varied widely across regions and states, reflecting the heterogenous economic conditions, urban development patterns, and levels of industry concentration. For the United States in 2013, employment contributions averaged $0.6 \mathrm{jobs} / \mathrm{mile}^{2}$ of land area and 6.4 jobs per 1000 population, while GDP contributions averaged $\$ 34,176 / \mathrm{mile}^{2}$ and $\$ 382 /$ person
(Table 5). States with the highest economic contributions per square mile were in relatively small and densely populated areas: District of Columbia (16.6 jobs, \$991,300 GDP), New Jersey (8.5 jobs, $\$ 559,300$ GDP), Rhode Island (7.3 jobs, $\$ 431,900$ GDP), Connecticut (6.6 jobs, $\$ 423,800$ GDP), Massachusetts (5.7 jobs, \$361,400 GDP), and Maryland (4.8 jobs, $\$ 299,500$ GDP). Large, sparsely populated states such as Alaska, North Dakota, South Dakota, Montana, Wyoming, and New Mexico had economic contributions of less than 0.1 job and $\$ 7$ GDP $/$ mile $^{2}$. States with the highest employment contributions per 1000 persons population were Vermont (10.1 jobs), Florida (10.1), New Hampshire (9.2), North Dakota (9.1), Connecticut (8.8), Oregon (8.6), and Maine (8.5). States with the highest GDP contribution per person were North Dakota (\$603), Connecticut (\$571), Florida (\$553), Oregon (\$553), and Vermont (\$519). States with the lowest employment and GDP contributions per capita, all having less than 10 jobs per 1000 persons and less than $\$ 300$ GDP per person, included the District of Columbia, Louisiana, West Virginia, and New York, as well as large western states such as Alaska, Oklahoma, New Mexico, North Dakota, South Dakota, Idaho, and Utah.

During the 1980s and 1990s, the green industry was one of the fastest-growing sectors of the U.S. economy, due to robust demand for ornamental plants and related products and services from commercial and residential development and rising affluence. However, current trends and driving forces indicate that consumer demand is maturing, and industry growth is slowing. Obviously, the severe economic recession of 2007-09 placed considerable financial strain on these businesses, as well as most other sectors of the global economy due to reduced home values and home ownership rates, and declining disposable household income in inflation-adjusted terms. Since the previous study for 2007-08 (Hodges et al., 2011b), the total economic contributions of the overall U.S. green industry in 2013 increased by $4.4 \%$ for employment, $2.0 \%$ for output, and $2.7 \%$ for GDP, with values adjusted for inflation using the GDP Implicit Price Deflator (U.S. Department of Commerce, 2015a). The wholesale and retail distribution industry group had significantly increased employment contributions (+62.1\%), while landscape services increased only slightly $(+3.6 \%)$, and production and manufacturing decreased $(-37.3 \%)$. Note that somewhat different methods were used in the past studies, so the results are not strictly comparable. For example, the previous study used higher values for nursery and greenhouse production estimated from a national survey (Hodges et al., 2009) rather than official government economic data, so the decline observed for 2013 partly reflects this artifact of the research methodology. Compared with the previous study for 2002 (Hall et al., 2006), the total economic contributions of the industry in 2013 increased by $3.9 \%$ for employment, $10.9 \%$ for output, and $6.2 \%$ for GDP (inflation-adjusted). Over the 11year period of 2002-13, the annual GDP growth rate averaged $0.56 \%$ (not compounded). 
Table 5. Green industry employment and gross domestic product (GDP) contributions as a share of the total economy, per unit land area, and population in U.S. regions and states in 2013 (U.S. Department of Commerce, 2015d, 2015e).

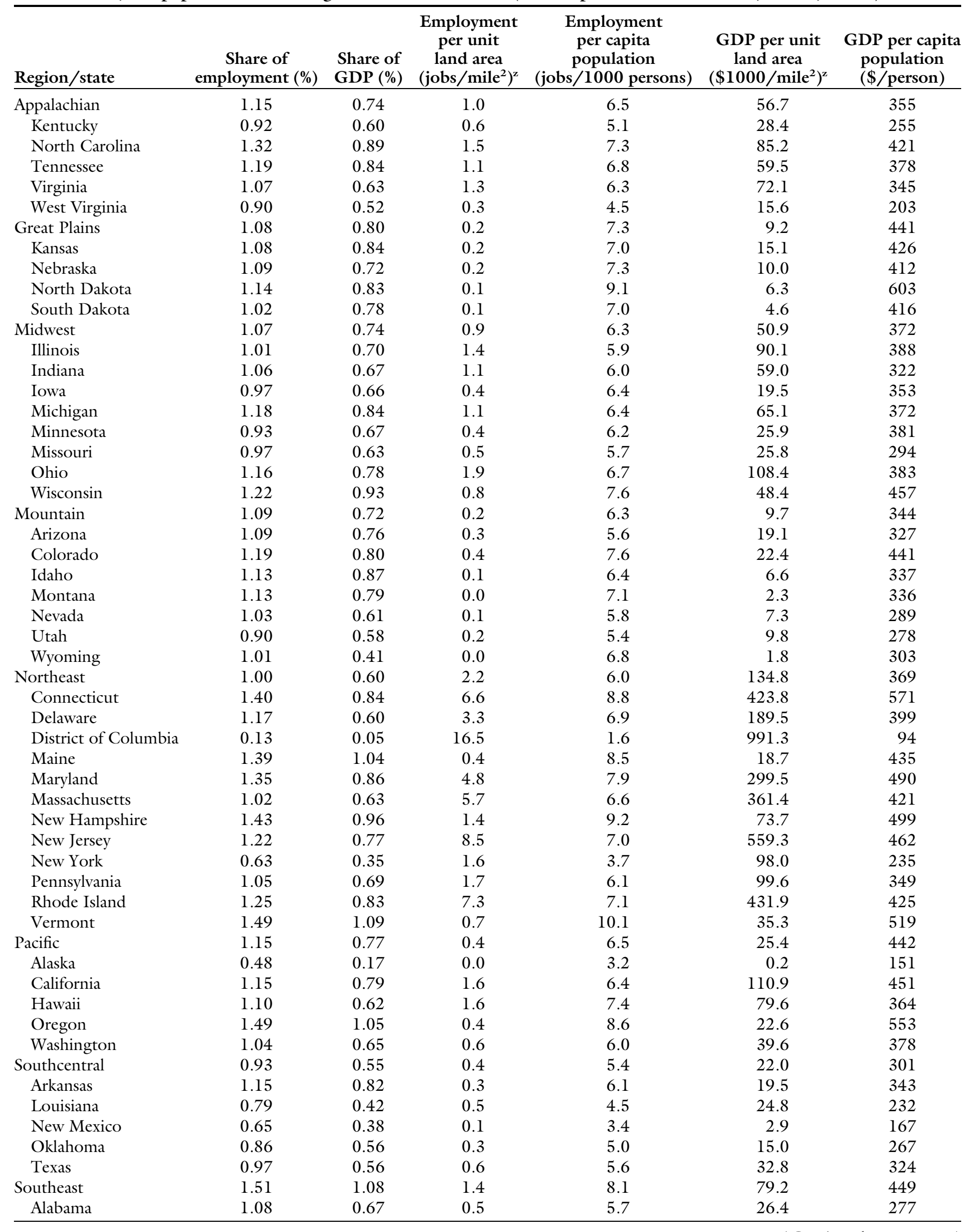

(Continued on next page) 
Table 5. (Continued) Green industry employment and gross domestic product (GDP) contributions as a share of the total economy, per unit land area, and population in U.S. regions and states in 2013 (U.S. Department of Commerce, 2015d, 2015e).

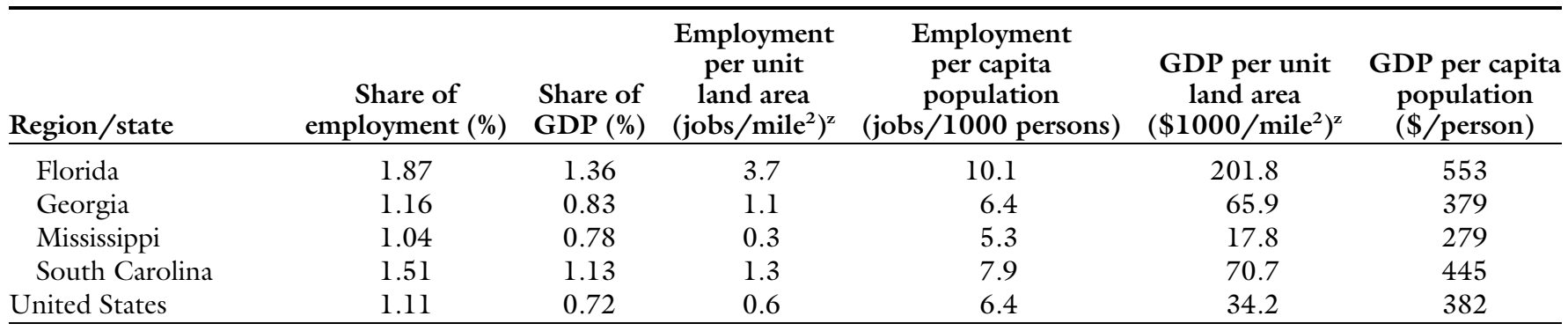

${ }^{\mathrm{z}} \mathrm{l} \mathrm{job} / \mathrm{mile}^{2}=0.3861 \mathrm{job} / \mathrm{km}^{2}, \$ 1000 / \mathrm{mile}^{2}=\$ 386.1022 / \mathrm{km}^{2}$.

In spite of slow growth or decreased activity in some sectors recent years, the green industry remains an important contributor to the U.S. economy, and to individual states and regions. The green industry is extremely broad based, with the landscape services and wholesale-retail trade sectors existing in virtually all communities in the nation, whereas the production and manufacturing sectors are concentrated in some states, and contribute disproportionately because of out-of-state shipments that bring new money into the local economies.

These findings are critical to our understanding of the structureconduct-performance issues affecting the green industry, as well as the economy at large. The results will help to enable participants in the green industry in making strategic decisions regarding future investments in their respective businesses. In addition, government policymakers and regulators will have better information to improve decisions regarding efficient allocation of resources (e.g., water and labor) among competing industries and interests.

\section{Literature cited}

Hall, C.R. 2010. Making cents of green industry economics. HortTechnology 20: 832-835.

Hall, C.R., A.W. Hodges, and J.J. Haydu. 2006. The economic impact of the green industry in the United States. HortTechnology 16:1-9.

Hodges, A.W., M.A. Palma, and C.R. Hall. 2009. Trade flows and marketing practices within the U.S. nursery industry,
2008. Southern Coop. Ser. Bul. 411. 1 Oct. 2015. <http://aggie-horticulture. tamu.edu/faculty/hall/publications / scsb411.pdf>.

Hodges, A.W., C.R. Hall, and M.A. Palma. 2011b. Economic contributions of the green industry in the United States in 2007-08. HortTechnology 21:628638.

Hodges, A.W., T.J. Stevens, M. Rahmani, and $\mathrm{H}$. Khachatryan. 2011a. Economic contributions of the Florida environmental horticulture industry in 2010. 27 Oct. 2015. <http://www.fred.ifas.ufl. edu/pdf/economic-impact-analysis / Economic_Contributions_Florida Environmental_Horticulture_Industry_ 2010.pdf>.

Hinson, R.A., R. Pinel, and D.W. Hughes. 2003. Louisiana's green industry: Evaluation of its economic contribution. Louisiana State Univ. Agr. Ctr. Res. Info. Sheet 108. 27 Oct. 2015. <https://www.lsuagcenter.com/NR/ rdonlyres/BFEE68F0-DC32-48379 AC 1 - A 200 B D 57 C $973 / 4111 /$ RIS108GreenIndustry6.pdf>.

IMPLAN Group, LLC. 2015. IMPLAN impact analysis and social accounting software, and U.S. state and county data package for 2013, release 3, June 2015 . IMPLAN Group, Huntersville, NC.

Miller, R.E. and P.D. Blair. 2009. Inputoutput analysis: Foundations and extensions. 2nd ed. Cambridge Univ. Press, New York, NY.

Thilmany, D., P. Watson, and S. Davies. 2003. The economic contribution of Colorado's green industry: Revenue and employment trends. 27 Oct. 2015. <http://ghex.colostate.edu/pdf_files/ greenco-final.pdf>.

U.S. Department of Agriculture. 2000. Farm resource regions. Agr. Info. Bul.
760. I May 2015. <http://www.ers. usda.gov/media/926929/aib-760_002. $\mathrm{pdf}>$.

U.S. Department of Commerce. 2009. 2007 Economic census, subject series, retail product line statistics for the U.S. and states. U.S. Dept. Commerce, Census Bureau, Washington, DC.

U.S. Department of Commerce. 2015a. U.S. Gross Domestic Product implicit price deflator, 1947 to present, quarterly. 1 Aug. 2015 . <http://research. stlouisfed.org.fred2/data/gdpdef.txt>.

U.S. Department of Commerce. 2015b. 2012 Economic census, subject series, retail product line statistics for the U.S. 1 May 2015. <http://factfinder.census. gov>.

U.S. Department of Commerce. 2015c. North American Industry Classification System lookup tool. I May 2015. <http://www.census.gov/eos/naics>.

U.S. Department of Commerce. 2015d. State area measurements (2010). I May 2015. <http://www.census.gov/geo/ reference/state-area.html>.

U.S. Department of Commerce. 2015e. State population estimates, 2013. 1 May 2015 . <http://www.census.gov/ popest/data/state/totals/2013>.

U.S. Department of Labor. 2015. Quarterly census of employment and wages, data for all employees and all establishment sizes in selected industries, 20012013. I May 2015. <http://www.bls. gov/cew>.

Watson, P., J. Wilson, D. Thilmany, and S. Winter. 2007. Determining economic contributions and impacts: What is the difference and why do we care? J. Regional Analysis Policy 37:140-146. 